\title{
Temperature-dependent expression of cytochrome-c oxidase in Antarctic and temperate fish
}

\author{
I. HARDEWIG, ${ }^{1}$ P. L. M. VAN DIJ K, ${ }^{1}$ C. D. MOYES, ${ }^{2}$ AND H. O. PÖRTNER ${ }^{1}$ \\ ${ }^{1}$ Alfred Wegener Institute for Polar and Marine Research, Biology I/ E cophysiology, \\ 27568 Bremerhaven, Germany; and 2Department of Biology, \\ Queen's University, Kingston, Ontario, Canada K7L 3N6
}

\begin{abstract}
Hardewig, I., P. L. M. van Dijk, C. D. Moyes, and H. O. Pörtner. Temperature-dependent expression of cytochrome-c oxidase in Antarctic and temperate fish. Am. J . Physiol . 277 (Regulatory Integrative Comp. Physiol. 46): R508-R516, 1999. - Seasonal acclimation versus permanent adaptation to low temperatures leads to a differential response in the expression of cytochrome-c oxidase (CCO) in temperate and Antarctic eelpouts. Although eurythermal eelpout from the N orth Sea (Zoarces vi vi parus) displayed a cold-induced rise of CCO activity in white muscle, enzyme activity in the cold stenothermal Antarctic eelpout Pachycara brachycephalum failed to reflect such a compensatory increase. In Antarctic eelpout, CCO activity correlates with transcript levels of mitochondrial encoded subunits of CCO (CCO I and CCO II), whereas cold-acclimated eel pout from the North Sea show lower enzyme activities than expected on the basis of mitochondrial mRNA levels. In these animals, CCO expression at low temperatures may be limited either by nuclear CCO transcripts or by posttranscriptional processes. These may comprise translation of the subunits or assembly of the CCO holoenzyme. mRNA levels of CCO IV, one of the nuclear encoded subunits, increased strongly during cold acclimation, indicating that the expression of CCO is likely not message limited in cold-acclimated Z. viviparus. Our data suggest that seasonal cold acclimation of $Z$. viviparus results in a modification of the relationship between transcription and translation or posttranslational processes. In permanently cold-adapted P. brachycephalum, on the other hand, CCO expression shows similar characteristics as in the warm-acclimated confamilial species, e.g., low levels of enzyme activity correlated with low levels of mitochondrial message.
\end{abstract}

Antarctic fish; Zoarcidae

IN ECTOTHERMIC ORGANISMS, long-term cold exposure leads to an array of adaptational physiological changes to compensate for the decel erating effect of low temperatures on metabolic processes. One of these compensatory mechanisms is the proliferation of mitochondria, which is reflected in enhanced mitochondrial densities in tissues of temporarily cold-acclimated as well as in permanently cold-adapted fish $(11,23)$. The increase in the number of mitochondria is usually associated with an increase in tissue-specific activity of cytochrome-c oxidase (CCO). Several studies have shown that acdimation to low temperatures provokes a compensatory increase of CCO activity in fish tissues $(2,42,46)$.

The costs of publication of this article were defrayed in part by the payment of page charges. The article must therefore be hereby marked "advertisement" in accordance with 18 U.S.C. Section 1734 solely to indicate this fact.
The CCO enzyme complex consists of 13 subunits, three of which are encoded on mitochondrial DNA (mtDNA), whereas the remaining 10 subunits are encoded in the nuclear genome. Several studies on CCO expression in mammalian tissues suggest that levels of mitochondrial encoded rather than nuclear encoded subunits are limiting for the assembly of the CCO holoenzyme (19; see Ref. 24). Therefore, the present study concentrates mainly on temperature effects on the expression of mitochondrial-encoded CCO subunits. The circular mtDNA codes for 2 rRNAs, 13 mRNAs, and several tRNAs. mtDNA possesses only one transcription initiation site, which is located upstream from the rRNA coding regions. Transcription can either be terminated after the two rRNAs have been synthesized or proceed until the entire $\mathrm{H}$ strand is transcribed into one polycistronic message that is processed into individual mRNAs. Therefore, proteinencoding mitochondrial genes are transcribed with a 1:1 stoichiometry, whereas rRNAs are usually transcribed at higher rates (see Ref. 5).

Biogenesis of mitochondria in response to physiological stimulation has been subject to a number of investigations on mammalian tissues. From these studies it appears that physiological stimuli (electrical stimulation of skel etal muscle or cold exposure of liver or brown adipose tissue) induce a coordinate upregulation of both nuclear and mitochondrial-encoded CCO transcripts $(21,24,29)$. Different mechanisms have been described to achieve the coordinate expression of both genomes. Common transcription factors (e.g., MT 3 and MT 4) may directly enhancethetranscription of nuclear as well as mitochondrial genes, or nuclear transcription factors indirectly influence mitochondrial gene expression (see Ref. 30). The nuclear transcription factors NRF-1 and NRF-2 control not only the expression of a variety of nuclear genes coding for proteins involved in oxidative phosphorylation but also the expression of the nuclear-encoded mitochondrial transcription factor A, which regulates mitochondrial transcription (see Ref. 30). This mechanism may ensure that the induction of NRF-1 or -2 leads to a coordinate expression of both nuclear and mitochondrial CCO genes.

In mammalian tissues, the increased expression of CCO in response to physiological stimuli is achieved not only by an increase in CCO-specific message but al so by enhanced translation rates $(21,24)$. I n ectothermic organisms, increased CCO expression during cold exposure is aggravated by the inhibitory effect of low temperature on biochemical reactions. Net CCO synthesis must be upregulated despite the decelerating effect of low temperatures. This can be achieved by a relative 
increase of CCO synthesis over degradation rates. Whereas for most metabolic processes complete temperature compensation is sufficient to maintain the physiological steady state despitetemperature changes, the cold-induced enzyme expression may require an overcompensation of the rates of transcriptional and/or translational processes if the protein half-life remains unchanged. Therefore, the investigation of cold-induced gene expression is especially interesting in ectothermic organisms, where physiological processes are directly affected by environmental temperature change.

The aim of this study was to investigate by which mechanisms cold exposure alters the expression of CCO in eurythermal and cold stenothermal fish.

To this end we compared confamilial species of eelpout (Zoarcidae) that are either permanently adapted tolow temperatures $\sim 0^{\circ} \mathrm{C}$ (Pachycara brachycephalum from the Antarctic) or that have been temporarily accl imated to the same low temperature (Zoarces viviparus from the North Sea). With this approach we wanted to identify possible differences in seasonal as opposed to evolutionary adaptation to cold.

\section{MATERIAL AND METHODS}

Animals. Benthic eel pout, P. brachycephalum, were caught at a depth of $500 \mathrm{~m}$ in the vicinity of King George I sland $\left(61^{\circ}\right.$ $\left.43.3^{\prime} \mathrm{S}, 59^{\circ} 12.5^{\prime} \mathrm{W}\right)$ on a cruise with the research vessel "Polarstern" in December 1996. Fish (length = 27.7 $\pm 2.4 \mathrm{~cm}$ ) were kept in well-aerated water of $0.0 \pm 0.5^{\circ} \mathrm{C}$ under permanent dim light for $1 \mathrm{wk}$ before being killed. The animals appeared to have been feeding well before capture, but they were starved during captivity. $Z$. viviparus, a related species from temperate waters, were caught in trawls in the German North Sea during the winter of 1997-1998. Fish (length = $22.6 \pm 4.7 \mathrm{~cm}$ ) were acclimated to $0.0 \pm 0.5^{\circ} \mathrm{C}$ and $18 \pm 1^{\circ} \mathrm{C}$ for at least 2 mo. Animals were kept under a 12:12-h light-dark cycle and were fed ad libitum twice a week.

Enzyme activity. Animals were anesthetized slightly with MS-222 $(0.3 \mathrm{~g} / \mathrm{l})$ before being killed. Samples of white musculature and liver were removed quickly and were instantaneously frozen in liquid nitrogen. Previous tests showed that this treatment of thetissues does not lead to a significant loss of enzyme activity. More than $95 \%$ of CCO activity was recovered in frozen tissues. Tissues were pulverized under liquid nitrogen in 9 vol buffer $(20 \mathrm{mM}$ Tris $\cdot \mathrm{HCl}, \mathrm{pH} 7.4,1 \mathrm{mM}$ EDTA, $0.1 \%$ Tween 20) and homogenized briefly with an Ultra Turrax. CCO activity was determined according to Moyes et al. (31) in $20 \mathrm{mM}$ Tris. $\mathrm{HCl}, \mathrm{pH}$ 8.0, 0.5\% Tween 20, $0.05 \mathrm{mM}$ reduced cytochrome c. Cytochrome $c$ was reduced by addition of excess sodium dithionite, which was removed by G-25 gel filtration. The decrease of the extinction at $\lambda=550$ $\mathrm{nm}$ was followed in a thermostatted spectrophotometer at 0 , 9 , and $18^{\circ} \mathrm{C}$. Enzyme activity in units per gram tissue was calculated using an extinction coefficient $\left(\epsilon_{550}\right)$ for cytochrome c of $19.1 \mathrm{mmol} / \mathrm{cm}$.

Construction of CDNA probes. Mouse CCO I, mouse CCO IV (25), mouse CCO II (31), and rat 16S (25) were constructed by PCR from cellular DNA and cloned into the plasmid pCR-II . A human 185 probe was kindly provided by Dr. Eric Shoubridge (McGill Neurological I nstitute). Plasmids were digested with EcoR I, and the insert of interest was gel purified and quantified by ethidium bromide staining. About $50 \mathrm{ng}$ doublestranded cDNA was radiolabel ed with $50 \mu \mathrm{Ci}$ [32P]dCTP using the random primer-based Ready-to-Go kit (Pharmacia) and purified on $\mathrm{G} 25$ columns.
Extraction and analysis of total RNA. Total RNA was recovered from frozen tissue by phenol-chlor oform extraction according to Chomczynski and Sacchi (4). Precipitated RNA of liver samples was washed twice in $4 \mathrm{M} \mathrm{LiCl}$ to remove glycogen. Total RNA was quantified spectrophotometrically in triplicate. $A_{280}: A_{260}$ ratios were $>1.8$. Total RNA $(5 \mu \mathrm{g})$ was glyoxylated according to Ausubel et al. (1), and electrophoresis was performed on a $1 \%$ agarose gel at $4 \mathrm{~V} / \mathrm{cm}$. RNA was transferred to Duralon nylon membrane (Stratagene) by capillary transfer overnight in $20 \times$ SSC $(1 \times$ SSC is $0.15 \mathrm{M}$ $\mathrm{NaCl}$ and $0.015 \mathrm{M}$ sodium citrate, $\mathrm{pH}$ 7.0). The membrane was washed briefly in $2 \times$ SSC and ultraviol et crosslinked.

The membrane was prehybridized in $6 \times$ SSC, $2 \times$ Denhardt's reagent, and $0.1 \%$ SDS for $2-3 \mathrm{~h}$ at the respective hybridization temperature (see RESULTS). After addition of the radiolabeled CDNA probe, the membrane was hybridized for $24 \mathrm{~h}$ at $42^{\circ} \mathrm{C}$ (for $\mathrm{CCO} \mathrm{I}, \mathrm{II}$, and IV and $16 \mathrm{~S}$ ) or at $60^{\circ} \mathrm{C}$ (for 18S). Subsequently, the membrane was washed twice ( $15 \mathrm{~min}$ each) in $1 \times$ SSC, $0.1 \%$ SDS, and twice (15 min each) in $0.25 \times$ SSC, $0.1 \%$ SDS, at hybridization temperature. The intensity of bands was quantified by phosphoimaging using Molecular Dynamics phosphoimager and ImageQuant software at the Queens University Cancer Research Laboratory.

Statistical analysis. Statistical significance was tested at the $P \leq 0.05$ level using ANOVA and the post hoc StudentNewman-Keuls test for independent samples. Data are given as means $\pm \mathrm{SE}$.

\section{RESULTS}

In thefollowing, warm-acclimated Z. viviparus served as control group for both cold-acdimated as well as cold-adapted eelpout to reveal differential effects of seasonal versus permanent latitudinal cold on the expression of CCO.

CCO activity in muscleand liver tissue CCO activity was determined at 0,9 , and $18^{\circ} \mathrm{C}$ in all experimental groups. $\mathrm{Q}_{10}$ values of enzyme activity were not significantly different between groups and ranged between 1.4 and 1.5 (data not shown). Enzyme activities can, therefore, be compared at an intermediate temperature of $9^{\circ} \mathrm{C}$ (see Fig. 1). Cold acclimation of the North Sea eel pout Z. viviparus led to a 1.5 -fold increase of CCO activity in the white musculature but not in liver tissue. I n contrast, Antarctic eel pout showed minor cold compensation of $\mathrm{CCO}$ activity in the white muscle and even negative compensation in the liver. In these animals, enzyme activity amounted to 123 and $57 \%$ of the control value in muscle and liver, respectively.

Amounts and integrity of RNA and validation of probes. Cold acclimation provoked a significant increase of total RNA in the white musculature of Z. viviparus. The same trend was observed in liver tissue; however, the differences were less pronounced. In both tissues of the Antarctic species, RNA concentrations were similar to those of the warm-acclimated reference group from the North Sea (see Table 1). Isolated RNA showed little contamination with proteins as indicated by high $\mathrm{A}_{260}: \mathrm{A}_{280}$ ratios ( $\left.>1.8\right)$. Northern blot analysis with different probes showed single bands in all cases without smears of lower molecular mass (Fig. 2).

A comparison of mRNA levels between species requires the use of a probe that binds with similar affinity 
A

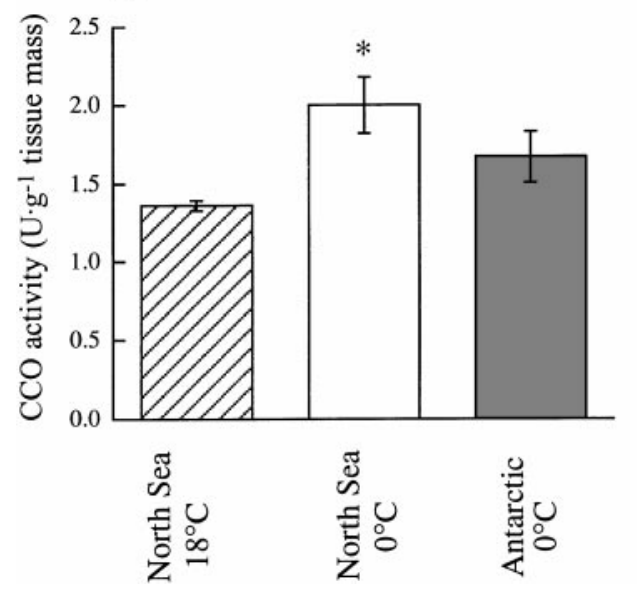

B

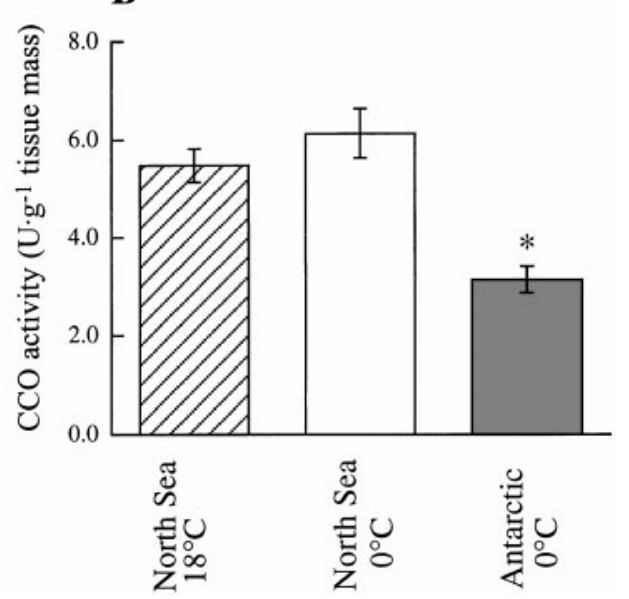

Fig. 1. Activity of cytochrome-coxidase (CCO) in muscle (A) and liver (B) tissue of North Sea eelpout (Z. viviparus) acclimated to $18^{\circ} \mathrm{C}$ and $0^{\circ} \mathrm{C}$ and of Antarctic eel pout (P. brachycephalum) adapted to $0^{\circ} \mathrm{C}$. Enzyme activity is depicted for an intermediate temperature of $9^{\circ} \mathrm{C}$. *Significant difference from warm-acclimated control group.

to the mRNA from both species. We chose to use mammalian probes, which should be equally genetically distant from both eel pout species. Furthermore, we used low stringent hybridization conditions to make sure that small differences in sequence between species did not result in different affinities of the mRNAs to the probe. The validity of this approach is supported by the constant ratio of the CCO I to CCO II signal between species (Table 1). A constant ratio of mitochondrial transcripts (except for 16S RNA) can be expected, because the mitochondrial genome is transcribed into one polycistronic mRNA. Therefore, it is likely that differences in the band intensity of Northern blots do reflect differences in mRNA concentrations rather than sequence differences between groups.

Levels of mitochondrial CCO message Cold acclimation as well as cold adaptation leads to an increase of both CCO I and CCO II mRNA in the white musculature when expressed per microgram total RNA (Fig. 3, left). However, a meaningful comparison of RNA levels

Table 1. Amounts of total RNA and ratios of different mitochondrial transcripts in muscleand liver tissue of $Z$. viviparus and P. brachycephalum

\begin{tabular}{|c|c|c|c|c|}
\hline Tissue & $\begin{array}{l}\mathrm{Acd} T, \\
{ }^{\circ} \mathrm{C}\end{array}$ & $\begin{array}{l}\text { Total RNA, } \\
\mathrm{mg} / \mathrm{g} \text { tissue }\end{array}$ & $\begin{array}{c}\text { CCO } \\
\text { । :CCO II }\end{array}$ & 16S:CCO I \\
\hline \multicolumn{5}{|c|}{ Whitemuscle } \\
\hline P. brachycephalum & $\begin{array}{r}18 \\
0 \\
0\end{array}$ & $\begin{array}{ll}5 & 0.56 \pm 0.04 \\
6 & 1.14 \pm 0.09 * \\
5 & 0.50 \pm 0.04\end{array}$ & $\begin{array}{l}1.14 \pm \\
1.06 \pm \\
0.99 \pm\end{array}$ & $\begin{array}{r}9.1 \\
12.1 \\
10.4\end{array}$ \\
\hline \multicolumn{5}{|c|}{ Liver } \\
\hline P. brachycephalum & $\begin{array}{r}18 \\
0 \\
0\end{array}$ & $\begin{array}{ll}4 & 3.51 \pm 0 . \\
5 & 5.35 \pm 0 . \\
5 & 3.91 \pm 0 .\end{array}$ & $\begin{array}{l}1.07 \pm 0.06 \\
1.40 \pm 0.11 \\
1.33 \pm 0.18\end{array}$ & $\begin{array}{r}7.47 \\
12.31 \\
16.36\end{array}$ \\
\hline \multicolumn{5}{|c|}{$\begin{array}{l}\text { Values are means } \pm \text { SE. It should be noted that ratios do not give } \\
\text { information of absolute concentration ratios of transcripts, because } \\
\text { Northern blot analysis only determines relative amounts of RNA } \\
\text { Differences in ratios between groups indicate relative differences in } \\
\text { the differential expression of transcripts. Accl T, acclimated tempera- } \\
\text { ture; CCO, cytochrome-c oxidase. * Significant difference from the } \\
\text { warm acdimated control group. CCO I:CCO II ratio in liver of } \\
\text { cold-acclimated Z. viviparus was significantly different from the ratic } \\
\text { found in white muscle of P. brachycephalum but not from other } \\
\text { values. }\end{array}$} \\
\hline
\end{tabular}

with enzyme activity is only possible if both parameters are expressed on the basis of a common denominator. Therefore, we calculated the amounts of mitochondrialencoded CCO mRNA per gram tissue mass and found that white muscle of cold-acclimated Z. viviparus contained 2.6-2.8 times more CCO message than white muscle from warm-acclimated animals. However, mitochondrial CCO message was not significantly higher in Antarctic eel pout compared with the control group (Fig. 3 , right). A different picture emerges from the liver tissue; whereas cold- and warm-acclimated Z. viviparus had the same amount of mitochondrial CCO message per microgram total RNA, Antarctic eel pout showed lower levels of CCO mRNA (Fig. 4, left). When expressed per gram tissue mass, levels of CCO transcripts were slightly, but not significantly, higher in cold- than in warm-acclimated Z. viviparus. Antarctic eel pout showed the lowest concentrations of mitochondrial CCO message of all three groups (Fig. 4, right).

Levels of 16S RNA. Levels of 16S RNA were significantly increased in the white muscle of cold-acclimated Z. viviparus. Antarctic eelpout showed higher $16 \mathrm{~S}$ levels per microgram total RNA than the control group; this difference disappeared, however, when expressed on a per gram tissue mass basis (Fig. 3). As mentioned above, all mitochondrial mRNAs are usually transcribed with a 1:1 stoichiometry, whereas mitochon-

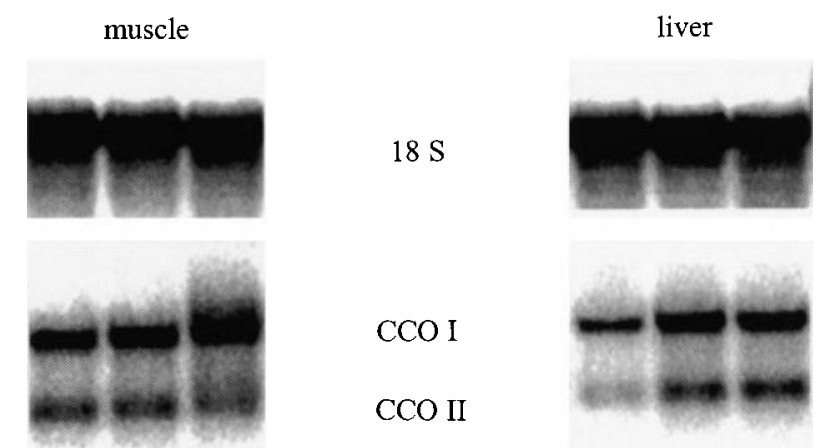

Fig. 2. Northern blot analysis of $5 \mu$ total RNA probed for $18 \mathrm{~S}, \mathrm{CCO}$ I, and CCO II. Left, lanes 1-3: muscle; $Z$. viviparus $18^{\circ} \mathrm{C}, Z$. viviparus $0^{\circ} \mathrm{C}$, P. brachycephalum $0^{\circ} \mathrm{C}$. Right, lanes 4-6: liver; P. brachycephalum $0^{\circ} \mathrm{C}, \mathrm{Z}$. viviparus $18^{\circ} \mathrm{C}$, Z viviparus $0^{\circ} \mathrm{C}$ 

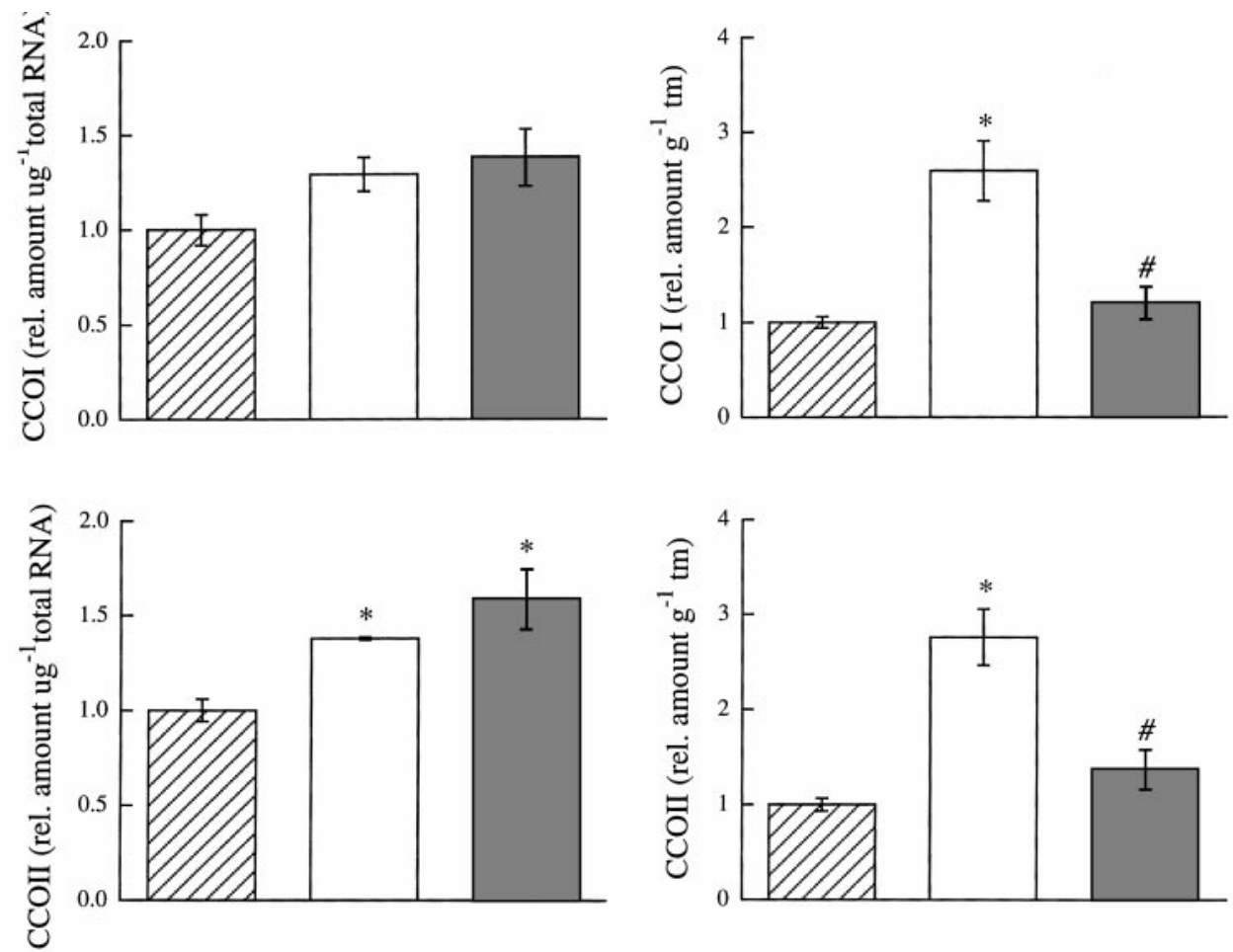

Fig. 3. Levels of mitochondrial transcripts in white musculature of North Sea eel pout (Z. vivi parus) acclimated to 18 and $0^{\circ} \mathrm{C}$ and of Antarctic eelpout (P. brachycephalum). Data were corrected using $18 \mathrm{~S}$ signal. Left: relative amount of specific RNA per $\mu \mathrm{g}$ total RNA. Right: relative amount of specific RNA per gram tissue mass. Values are expressed relative to warm-acclimated control group, which was set to $1 . *$ Significant difference from warm-acclimated control group. \#Significant difference from $0^{\circ} \mathrm{C}$-acclimated North Sea
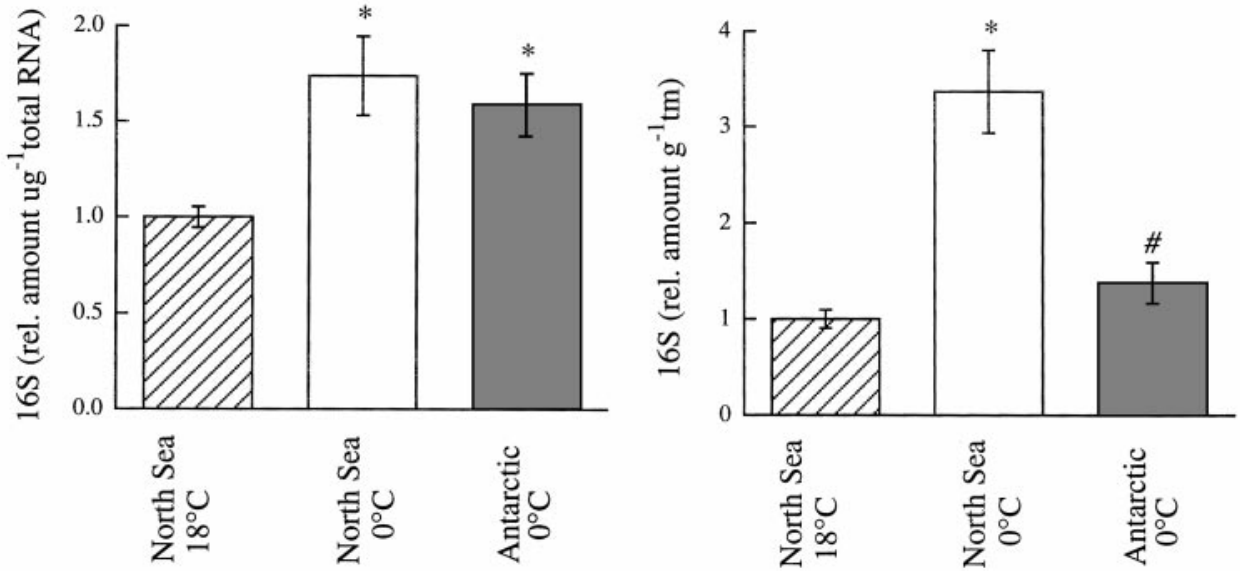
eel pout.

drial rRNA levels can be adjusted independently. Therefore, it makes sense to compare $16 \mathrm{~S}$ levels relative to mitochondrial mRNAs to reveal a relative increase of 16S, which may indicate an adaptive increase of the translational capacity of the mitochondria. In the white musculature, ratios of 165 over CCO I and CCO II message were constant between warm-acclimated $Z$. viviparus and Antarctic eel pout, but showed a trend to relatively higher $16 \mathrm{~S}$ concentrations in cold-acclimated Z. viviparus (Table 1 ). This trend was not significant, however. 16S levels in the liver tissue were increased after cold acclimation but were low in Antarctic eel pout (Fig. 4). Ratios of 16S over CCO I and CCO II, however, were significantly higher in liver of both cold-acclimated and cold-adapted fish (Table 1).

Levels of nuclear CCO message. To investigate whether temperature affects the expression of nuclear and mitochondrial CCO subunits in a coordinate fash- ion, as is suggested by several studies on mammalian tissues (see introduction), we determined levels of mRNA specific for CCO IV, a nuclear-encoded CCO subunit. During cold acclimation of Z. viviparus, CCO IV transcripts increased 3.3- and 3.7-fold per gram musde and liver tissue, respectively (see Table 2). This increase was stronger than that observed for the mitochondrially encoded message (2.6- to 2.8-fold increase in muscle; 1.2- to 1.6-fold increase in liver), indicating that there is a joint, but not a stoichiometric, increase of nudear and mitochondrial transcripts during cold acclimation.

In muscle and liver of the Antarctic eel pout, concentrations of CCO IV-specific message displayed huge individual variations. Surprisingly, CCO IV mRNA levels showed different trends than mitochondrial message for CCO I and II. Compared with the warmacclimated control group, CCO IV mRNA concentrations were low in muscle and high in liver. 
Fig. 4. Levels of mitochondrial transcripts in liver of North Sea eel pout ( $Z$. viviparus) acclimated to 18 and $0^{\circ} \mathrm{C}$ and of Antarctic eel pout (P. brachycephalum). Data were corrected using 185 signal. Left: relative amounts of specific RNA per $\mu \mathrm{g}$ total RNA. Right: relative amounts of specific RNA per gram tissue mass. Values are expressed relative to values found in white muscle of warm-acclimated control group, which was set to 1 . *Significant difference from warm-acclimated control group. \#Significant difference from $0^{\circ} \mathrm{C}$-acclimated N orth Sea eel pout.
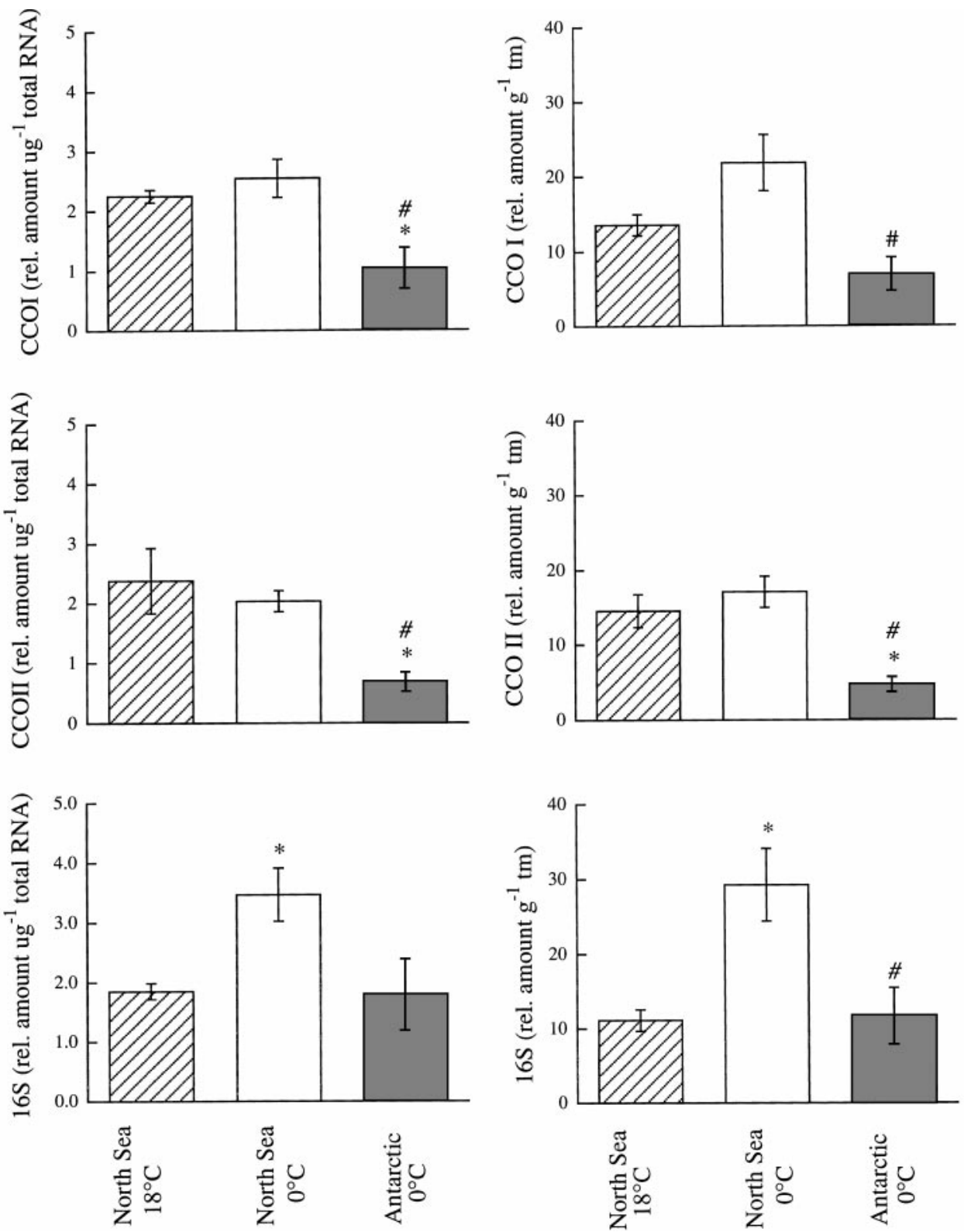

\section{DISCUSSION}

CCO acti vity. Acclimation to low temperatures generally leads to a compensatory increase of CCO in fish (2, $43,44)$. Enhanced enzyme activity in the cold can be achieved by modulation of the specific activity of the individual enzymemoleculeor by changes of theamount of enzyme per gram tissue. During thermal acclimation, CCO activity may be modulated by temperature dependent modification of the composition of mitochondrial membranes (homeoviscous response; 46). But because both cold acclimation and cold adaptation go along with an increase in mitochondrial volume density (11), it is likely that the adaptive increase of CCO activity is at least in part achieved by a rise of the number of CCO molecules. This has indeed been shown in goldfish, where the amount of CCO increased by $66 \%$ between 25 and $5^{\circ} \mathrm{C}(45)$.
Table 2. Levels of nuclear encoded transcripts for CCO IV subunit in muscleand liver tissue of $Z$. viviparus and P. brachycephalum

\begin{tabular}{|c|c|c|c|}
\hline Tissue & $\begin{array}{l}\text { Acd } T, \\
{ }^{\circ} \mathrm{C}\end{array}$ & $\begin{array}{l}\text { CCOIV, } \\
\text { rel. amount }\end{array}$ & $\begin{array}{l}\text { CCO IV, } \\
\text { rel. amount/g } \\
\text { tissue }\end{array}$ \\
\hline \multicolumn{4}{|c|}{ Whitemuscle } \\
\hline $\begin{array}{l}\text { Z. viviparus } \\
\text { P. brachycephalum }\end{array}$ & $\begin{array}{r}18 \\
0 \\
0\end{array}$ & $\begin{array}{l}1.00 \pm 0.19 \\
1.62 \pm 0.28 \\
0.52 \pm 0.24 *\end{array}$ & $\begin{array}{l}1.00 \pm 0.28 \\
3.33 \pm 0.75^{*} \\
0.51 \pm 0.28^{*}\end{array}$ \\
\hline \multicolumn{4}{|c|}{ Liver } \\
\hline $\begin{array}{l}\text { Z. viviparus } \\
\text { P. brachycephalum }\end{array}$ & $\begin{array}{r}18 \\
0 \\
0\end{array}$ & $\begin{array}{l}1.00 \pm 0.45 \\
2.38 \pm 0.49 \\
2.53 \pm 0.97\end{array}$ & $\begin{array}{l}1.00 \pm 0.26 \\
3.71 \pm 0.76 * \\
3.39 \pm 1.37\end{array}$ \\
\hline
\end{tabular}

Values are means $\pm \mathrm{SE}$. Amounts are expressed relative to the warm-acclimated control group. Data were corrected using the 18S signal. *Significant difference from warm-acclimated control group. 
In white musculature of the eurythermal eelpout from the North Sea (Z. viviparus), CCO activity increased 1.5-fold between 18 and $0^{\circ} \mathrm{C}$, which complies with partial temperature compensation (Precht type 3; 35). On the basis of the $Q_{10}$ value of 1.4-1.5 that we found for CCO activity, complete compensation would be achieved by a 1.8- to 2.1-fold increase in enzyme activity. Surprisingly, CCO activities in the Antarctic eel pout were only slightly, but not significantly, higher than in warm-acclimated $Z$. viviparus. This is surprising when our previous results on this species are considered. Resting levels of oxygen consumption are increased to the same extent in both cold-acclimated and cold-adapted eel pout (43). Additionally, Antarctic eel pout are able to recover faster from exhaustive exercise than cold-acclimated $Z$. viviparus at $0^{\circ} \mathrm{C}$, indicating a higher aerobic capacity of the Antarctic species (17). On the basis of these data, we had expected to find the same or even higher CCO activities in Antarctic eelpout compared with cold-acclimated North Sea animals. Crockett and Sidell (8) found 3.6-fold increased CCO activities in the white muscle from Antarctic versus temperate fish. Comparative investigations from Torres and Somero (41) showed higher activities of citrate synthase, another oxidative enzyme, in Antarctic than in Californian fish. However, this difference was only small and not significant. These two studies emphasize once again the difficulties comparing nonrelated species from different latitudes because large differences of physiological parameters are observed al so between species of the same thermal habitat. A comparison of confamilial species is less biased by interspecific variations and may, therefore, draw a more reliable picture.

The liver tissues of both species showed no or even inverse cold compensation with respect to CCO activity. The absence of cold compensation in liver tissue has al so been shown in gol dfish and channel catfish $(36,42)$. Cold exposure leads to a relative increase of liver mass as indicated by an increase of the hepatosomatic index (g liver/100 g fish; 3, 12, 36). Ther efore, cold compensation of the liver may be achieved on the whole organ rather than on the tissue level.

Expression of CCO. Levels of mitochondrial message (CCO I, CCO II, and 16S) per microgram total RNA are increased in the white musculature of both coldacclimated and cold-adapted eel pout (Fig. 3, left). This means, that in addition to a general increase of all RNA species, which is observed in $0^{\circ} \mathrm{C}$-acclimated $\mathrm{Z}$. viviparus (see Table 1), cold exposure leads to a specific increase of mitochondrial transcripts. This may be brought about either by enhanced transcription of the mitochondrial genome or by a higher stability of mRNA in the cold. Studies on mammalian tissues suggest that increases in mitochondrial gene expression areachieved by gene amplification. Higher mtDNA copy numbers lead to increased mitochondrial transcription rates and therefore higher transcript levels (44). An increase of mtDNA copy number seems likely to occur during cold acclimation or adaptation because of a generally ob- served rise in mitochondrial volume density under these conditions (11). However, cold acclimation of trout did not lead to significant increases of mtDNA in either white or red muscle (2). Cold exposure of rat induced an increase of mitochondrial volume density in liver tissue (15) correlated with higher levels of mitochondrial transcripts, but without a concomitant increase in mtDNA copy number (29). The authors ascribetheenhanced transcript levels to a general increase of mitochondrial transcription per DNA copy (29), but it may al so be caused by enhanced transcript stability. An intertissue comparison of mitochondrial determinants in trout also showed flexible relationships between mitochondrial transcripts and mtDNA copy number in different tissues (26), which correlates with differences in mRNA stability between tissues (6). There is more and more evidence that mRNA degradation rates are involved in the control of gene expression. Increased mRNA stability causes the increase in mitochondrial transcript levels during liver development in rat (33). Modulation of RNA stability as a mediator for coldspecific gene expression has been shown in winter flounder. Nuclear mRNA levels of type I antifreeze protein (AFP) increase as much as 1,000-fold during winter. This increase is at least partly due to higher stability of AF P mRNA at low temperatures (10). I n two studies on the effects of cold exposure on gene expression in fish, increases in message levels have been correlated with enhanced transcription rates. In a northern population of killifish F. heteroclitus, twofold higher levels of LDH-specific mRNA are brought about by twofold increased transcription rates compared with a southern population (7). Similarly, a transient increase of desaturase mRNA during cold acclimation of carp is correlated with an increase in desaturase gene transcription (40). Further investigations will show whether the observed increase in CCO message is due to changes in transcription or mRNA stability.

On first sight, levels of mitochondrial CCO-specific mRNA seem to reflect CCO activities in eel pout liver and white muscle. Closer analysis of the data, however, reveals that this is only the case for warm-acclimated $Z$. viviparus and for P. brachycephalum. Plotting normalized CCO activity versus normalized CCO I mRNA yields data points that lie on the line of identity, indicating that a doubling of message leads to a doubling of enzyme activity (Fig. 5A). The strong correlation between CCO message and CCO activity suggests that in these two groups of fish CCO activity is determined by the amount of mitochondrial CCO message.

In cold-acclimated Z. viviparus, transcript levels are no longer tightly correlated with enzyme activities (see Fig. 5A). These animals show a 2.6- to 2.8-fold increase of mitochondrial CCO mRNA, whereas enzyme activity increases only 1.5 -fold. A loosening of the correlation between CCO message and enzyme is also observed in the liver tissue of cold-acclimated Z. viviparus (Fig. $5 B$ ). Because these data suggest that CCO synthesis in cold-acclimated $Z$. vivi parus is not limited by mitochondrial message, two alternative explanations are possible. Either CCO synthesis is limited by transcript 

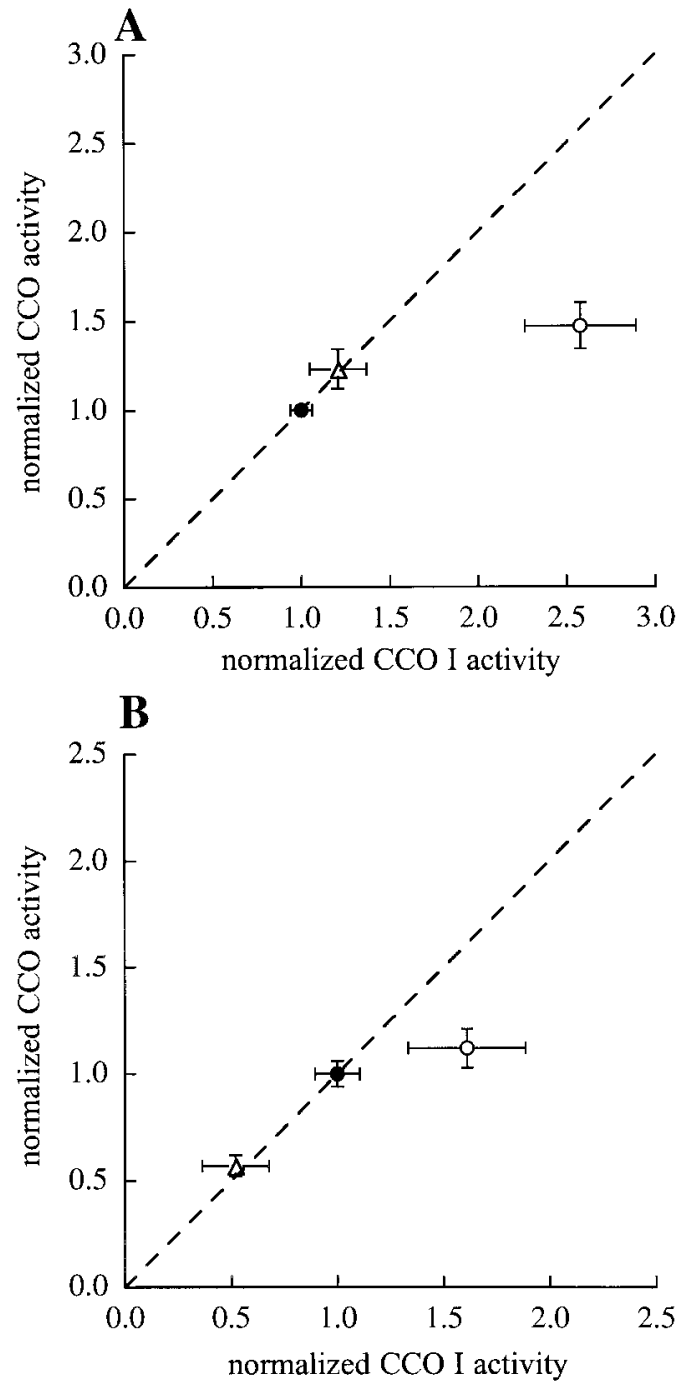

Fig. 5. CCO activity versus CCO I mRNA in muscle (A) and liver (B) tissues. Both enzyme activity and mRNA levels were normalized to tissue mass. RNA levels were corrected using $18 \mathrm{~S}$ signal. Data are expressed as a ratio relative to value obtained in warm-acclimated control group. $\bullet, 18^{\circ} \mathrm{C}$-acclimated Z. viviparus; $\bigcirc, 0^{\circ} \mathrm{C}$-acclimated $Z$. viviparus; $\triangle$, Antarctic eel pout.

levels of nuclear subunits or by the translational capacity of the mitochondrial or the cytosolic compartment. Studies on mammalian tissues suggest that levels of nuclear-encoded CCO subunits are not limiting CCO synthesis (19 and see Ref. 24). This is supported by our data that show that the transcript levels of the nuclearencoded CCO IV subunit are increased even more during cold acclimation than mitochondrial CCOspecific mRN As (see Table 2). Similarly, nuclear mRNA levels for respiratory proteins increase to a greater extent than do mitochondrial mRNA species in coldacclimated trout (2). Therefore, CCO expression in cold-acclimated Z. viviparus is likely not limited by mitochondrial or nuclear message.

Apparently, cold acclimation leads to an enhanced expression of both the nuclear and mitochondrial genome; nuclear message increases more strongly, however. The parallel increase of nuclear and mitochon- drial message may be simply due to similar effects of temperature on both nuclear and mitochondrial mRNA turnover, or it may involve a regulatory coordination of the two genomes via signal transduction pathways. A coordinate expression of nuclear and mitochondrially encoded subunits of CCO has been shown in different tissues of rat $(14,20)$. Furthermore, an equimolar upregulation of mitochondrial and nuclear CCO gene products occurs during biogenesis of mitochondria induced by chronic stimulation of rat skeletal muscle or cold exposure of brown adipose tissue $(21,24)$. A decrease of mitochondrial content in rat brown adipose tissue during lactation is correlated with a decrease in both mitochondrial- and nuclear-encoded CCO message (28). These results indicate a close coordination between the two genomes, possibly through the mitochondrial transcription factor A or common transcription factors that act on the nuclear as well as the mitochondrial genome (see introduction and Ref. 30). An uncoordinate expression of the two genomes, especially with respect to nuclear and mitochondrial CCO subunits, seems to be the exception, but has been observed in growing and differentiating 3T3 cells (27, 31).

Limitation of CCO expression on a posttranscriptional level. Our data suggest that in cold-acclimated eel pout CCO expression is not limited to the transcriptional but rather to the translational or posttranslational level.

An indicator of the translational capacity of a certain tissue is the amount of ribosomal RNA, assuming that the amount of rRNA correlates with the number of ribosomes (see Refs. 22, 40). Total RNA consists of 95-98\% cytosolic ribosomal RNA (22). Thus amounts of total RNA can be regarded as a measure of cytosolic rRNA levels. In Z. vivi parus, cold acclimation leads to a twofold increase of rRNA in the cytosol (as indicated by total RNA; Table 1) and an even 3.4-fold increase in mitochondrial rRNA (16S RNA; Fig. 3). This suggests that in $0^{\circ} \mathrm{C}$-acclimated $\mathrm{Z}$. viviparus, the translational machinery is cold compensated at least to some extent. An increase in total RNA with cold acclimation has also been observed in carp and cod $(13,16)$. A 1.3- to 2-fold increase of total RNA in different tissues of cod was correlated with a perfect compensation of total protein synthesis rates (13).

In Antarctic eel pout no compensatory increase of rRNA is observed. In both investigated tissues cytosolic as well as mitochondrial rRNA is as low as in the warm-acclimated reference group. Nevertheless, our data suggest that CCO synthesis is not limited by translational capacity, because CCO activity correlates with mitochondrial CCO transcripts (Fig. 5). This is confirmed by a study of Smith and Haschemeyer (38), who showed that translational activity at $0^{\circ} \mathrm{C}$ is higher in white muscle and liver of two Antarctic fish species than would be predicted from extrapolation of the data on temperate fish. High levels of elongation factor E F-1 are suggested to mediate the compensatory increase of the translatory capacity (18). Apparently, Antarctic fish have upregulated the translational activity of the indi- 
vidual ribosomes, rather than increasing the number of ribosomes, which is involved in cold acclimation in the eurythermic species.

If thetranslational machinery is cold compensated in both species, the observed limitation of CCO synthesis in cold-acclimated $Z$. viviparus may then be due to temperature effects on the assembly of the CCO hol oenzyme. CCO assembly is known to be a slow process and may be rate limiting for CCO synthesis (33). Because temperature affects the kinetics and equilibria of weak, noncovalent molecular interactions, it will have a strong effect on protein assembly processes. These temperature effects may have been compensated in Antarctic eel pout by structural adaptations of the CCO subunits. Cold compensation of protein assembly processes has been shown for the polymerization of microtubuli in Antarctic fish (9).

\section{Perspectives}

Our data show that seasonal cold acclimation, as opposed to evolutionary adaptation to constantly cold conditions, displays different characteristics with respect to the expression of the oxidative enzyme CCO in fish. Although seasonally cold-acclimated eel pout show higher enzyme levels than the warm-acclimated control group, cold-adapted Antarctic fish fail to show this compensatory increase of enzyme activity. Adaptation as well as acclimation to cold goes along with an increase in mitochondrial density (11). However, the aerobic capacity of the individual mitochondrion is increased only during cold acclimation in eurythermal species, but remains low or is even reduced in stenothermal polar animals (34). This is in line with the observed differences in CCO activity in North Sea and Antarctic eelpout. Our data suggest that temperature-related differences in mitochondrial aerobic capacities between and within species are induced at the mRNA level. Fine regulation of the expression of oxidative enzymes may occur by translational or posttranslational regulation, as in the case of CCO synthesis in cold-acclimated Z. viviparus. Future studies will investigate which of the posttranscriptional processes are limiting during cold exposureand how these temperature effects are compensated in eurythermal versus stenothermal species.

We thank Scot Leary for advice and assistance during this project. This work was funded by a National Sciences and Engineering Research Council grant to C. D. Moyes, by a traveling grant of the "Fond der Chemischen I ndustrie" to I. Hardewig and P. van Dijk, and by a contribution from the "ELOISE project": effects of climate induced temperature change on marine coastal fishes (CLICOFI) ENV4-CT 97-0599 funded by the European Union. AWI publication no. 1604.

Present address for P. L. M. van Dijk: Institute for Freshwater Ecology, Dept. Biology of Fishes, POB 850119, 12561 Berlin, Germany.

Present address and address for reprint requests and other correspondence: I. Hardewig, Institute for F reshwater Ecology, Dept. Biology of Fishes, POB 850119, 12561 Berlin, Germany (E-mail: hardewig @igb-berlin.de).

Received 18 F ebruary 1999; accepted in final form 26 April 1999.

\section{REFERENCES}

1. Ausubel, F. M., R. Brent, R. E. Kingston, D. D. Moore, J . G. Seidman, J . A. Smith, and K. Struhl. Short Protocols in Molecular Biology. Toronto, Ontario: J ohn Wiley, 1992.

2. Battersby, B. J., and C. D. Moyes. Influence of acclimation temperature on mitochondrial DNA, RNA, and enzymes in skeletal muscle. Am. J. Physiol. 275 (Regulatory Integrative Comp. Physiol . 44): R905-R912, 1998.

3. Blier, P., and H. Guderley. Metabolic responses to cold acd imation in the swimming musculature of Lake Whitefish, Coregonus clupeaformis. J . Exp. Zool. 246: 244-252, 1988.

4. Chomczynski, P., and N. Sacchi. Single-step method of RNA isolation by acid guanidinium thiocyanate-phenol-chloroform extraction. Anal. Biochem. 162: 156-159, 1987.

5. Clayton, D. Replication and transcription of vertebratemitochondrial DNA. Annu. Rev. Cell Biol. 7: 453-478, 1991.

6. Connor, M. K., M. Takahashi, and D. A. Hood. Tissue-specific stability of nuclear- and mitochondrially encoded mRNAs. Arch. Biochem. Biophys. 333: 103-108, 1996.

7. Crawford, D. L., and D. A. Powers. Evolutionary adaptation to different thermal environments via transcriptional regulation. Mol. Biol. Evol. 9: 806- 813, 1992.

8. Crockett, E., and B. D. Sidell. Some pathways of energy metabolism are cold adapted in Antarctic fishes. Physiol. Zool. 63: 472-488, 1990.

9. Detrich, H. W. Microtubule assembly in cold-adapted organisms: functional and structural adapations of tubulins from Antarctic fishes. Comp. Biochem. Physiol. A Physiol. 118A: 501-513, 1997.

10. Duncker, B. P., M. D. Koops, V. Walker, and P. L. Davies. Low temperature persistence of type I antifreeze protein is mediated by cold-specific mRNA stability. FEBS Lett. 377: 185-188, 1995.

11. Dunn, J . F. Low-temperature adaptation of oxidative energy production in cold-water fishes. Can. J. Zool. 66: 1098-1104, 1988.

12. Foster, A. R., S. J . Hall, and D. F. Houlihan. The effects of temperature acclimation on organ/tissue mass and cytochrome $c$ oxidase activity in juvenile cod (Gadus morhua). J . Fish Biol . 42: 947-957, 1993

13. Foster, A. R., D. F. Houlihan, S. J . Hall, and L. J . Burren. The effects of temperature acclimation on protein synthesis rates and nucleic acid content of juvenile cod (Gadus morhua L.). Can. J . Zool. 70: 2095-2102, 1992.

14. Gagnon, J ., T. Kurowski, R. J . Wieser, and R. Zak. Correlations between a nuclear and a mitochondrial mRNA of cytochrome c oxidase subunits, enzyme activity and total mRNA content, in rat tissues. Mol. Cell. Biochem. 107: 21-29, 1991.

15. Goglia, F., G. Liverini, A. Lanni, S. Bottiglieri, and A. Barletta. Alteration in hepatic mitochondrial compartment of cold accl imated rats. Association with enhanced triiodothyronine serum levels. A morphometric/stereologic study by electron microscopy. Exp. Biol. 44: 41-56, 1985.

16. Goolish, E. M., M. G. Barron, and I. R. Adelmann. Thermoacclimatory response of nucleic acid and protein content of carp muscle tissue: influence of growth rate and relationship to glycine uptake by scales. Can. J . Zool. 62: 2164-2170, 1984.

17. Hardewig, I., P. L. M. van Dijk, and H. O. Pörtner. Highenergy turnover at low temperatures: recovery from exhaustive exercise in Antarctic and temperate eel pouts. Am. J . Physiol . 274 (Regulatory I ntegrative Comp. Physiol. 43): R1789-R1796, 1998.

18. Haschemeyer, A. E. V., and R. C. Williams. Temperature dependency of cell-free protein synthetic systems from Antarctic fish. Mar. Biol. Lett. 3: 81-88, 1982.

19. Heerdt, B. G., and L. H. Augenlicht. Effects of fatty acids on the expression of genes encoding subunits of cytochrome $c$ oxidase and cytochrome c oxidase activity in HT29 human clonic adenocarcinoma cells. J . Biol. Chem. 266: 19120-19126, 1991.

20. Hood, D. A. Co-ordinate expression of cytochrome c oxidase subunit III and VIC mRNAs in rat tissues. Biochem. J . 269: 503-506, 1990

21. Hood, D. A., R. Zak, and D. Pette. Chronic stimulation of rat skeletal muscle induces coordinate increases in mitochondrial and nuclear mRNAs of cytochrome c oxidase subunits. Eur. J . Biochem. 179: 275-280, 1989. 
22. Houlihan, D. F. Protein turnover in ectotherms and its relationships to energetics. In: Advances in Comparative and Environmental Physiology, edited by R. Gilles. Berlin: Springer Verlag, Berlin, 1991, vol. 7, p. 1-43.

23. J ohnston, I. A., J . Calvo, H. Guderley, D. Fernandez, and L. Palmer. Latitudinal variation in the abundance and oxidative capacities of muscle mitochondria in perciform fishes. J. Exp. Biol. 201: 1-12, 1998.

24. Klingenspor, M., M. Ivemeyer, H. Wiesinger, K. Haas, G. Heldmaier, and R. Wiesner. Biogenesis of thermogenic mitochondria in brown adipose tissue Djungarian hamsters during cold adaptation. Biochem. J . 316: 607-613, 1996.

25. Leary, S. C., B. J . Battersby, R. G. Hansford, and C. D. Moyes. Interactions between bioenergetics and mitochondrial biogenesis. Biochim. Biophys. Acta 1365: 522-530, 1998.

26. Leary, S. C., B. J . Battersby, and C. D. Moyes. Inter-tissue differences in mitochondrial enzyme activity, RNA and DNA in rainbow trout (Oncorhynchus mykiss). J . Exp. Biol. 201: 33773384, 1998.

27. Luciakova, K., R. Li, and B. D. Nelson. Differential regulation of the transcript levels of some nuclear-encoded and mitochondrial-encoded respiratory chain components in response to growth activation. Eur. J. Biochem. 207: 253-257, 1992.

28. Martin, I., M. Giralt, O. Vinas, R. I glesias, T. Mampel, and F. Villarroya. Co-ordinate decrease in the expression of the mitochondrial genome and nuclear genes for mitochondrial proteins in the lactation-induced mitochondrial hypotrophy of rat brown fat. Biochem. J. 308: 749- 752, 1995.

29. Martin, I., O. Vinas, T. Mampel, R. Iglesias, and F. Villarroya. Effects of cold environment on mitochondrial genome expression in the rat: evidence for a tissue-specificincrease in the liver, independent of changes in mitochondrial gene abundance. Biochem. J . 296: 231-234, 1993.

30. Moyes, C. D., B. Battersby, and S. C. Leary. Regulation of muscle mitochondrial design. J . Exp. Biol. 201: 299- 307, 1998.

31. Moyes, C. D., O. A. Mathieu-Costello, N. Tsuchiya, C. Filburn, and R. G. Hansford. Mitochondrial biogenesis during cellular differentiation. Am. J. Physiol. 272 (Cell Physiol. 41): C1345-C1351, 1997.

32. Nijtmans, L. G. J ., J. W. Taanman, A. O. Muijsers, D. Speijer, and C. van den Bogert. Assembly of cytochrome c oxidase in cultured human cells. Eur. J . Biochem. 254: 389-394, 1998.

33. Ostronoff, L. K., J . M. Izquierdo, and J . M. Cuezva. mtmRNA stability regulates the expression of the mitochondrial genome during liver devel opment. Biochem. Biophys. Res. Commun. 217: 1094-1098, 1995.

34. Pörtner, H. O., I. Hardewig, F. J . Sartoris, and P. L. M. van Dijk. Energetic aspects of cold adaptation: critical temperatures in metabolic, ionic and acid-base regulation? In: Cold Ocean Physi ol ogy, edited by H. O. Pörtner and R. C. Playle. Cambridge: Cambridge University Press, 1998, p. 88-120.

35. Precht, H., J . Christophersen, and J . Hensel. Temperatur und Leben. Berlin: Springer Verlag, 1955, p. 514.

36. Seddon, W. L., and C. L. Prosser. Seasonal variations in the temperature acclimation response of the channel catfish, Ictalurus punctatus. Physiol. Zool. 70: 33-44, 1997.

38. Smith, M. A. K., and A. E. V. Haschemeyer. Protein metabolism and cold adaptation in Antarctic fishes. Physiol. Zool. 53: 373-382, 1980

39. Sudgen, P. H., and S. J. Fuller. Regulation and protein turnover in skeletal and cardiac muscle. Biochem. J . 273: 21-37, 1991.

40. Tiku, P. E., A. I. Gracey, R. J . Beynon, and A. R. Cossins. Cold-induced expression of $\Delta^{9}$-desaturase in carp by transcriptional and posttranslational mechanisms. Science 271: 815-818, 1996.

41. Torres, J. J ., and G. N. Somero. Metabolism, enzymatic activities and cold adaptation in Antarctic mesopelagic fishes. Mar. Biol. (Berl.) 98: 169-180, 1988.

42. Van den Thillart, G., and J. Modderkolk. The effect of acclimation temperature on the activation energies of state III respiration and the unsaturation of membrane lipids of gold fish mitochondria. Biochim. Biophys. Acta 510: 38-51, 1978.

43. Van Dijk, P. L. M., C. Tesch, I. Hardewig, and H. O. Pörtner. Physiological disturbances at critically high temperatures. A comparison between stenothermal Antarctic and eurythermal temperate eel pouts (Zoarcidae). J . Exp. Biol. In press.

44. Williams, R., S. Salmons, E. A. Newsholme, R. E. Kaufman, and J . Mellor. Regulation of nuclear and mitochondrial gene expression by contractile activity in skeletal muscle. J. Biol. Chem. 261: 376- 380, 1996.

45. Wilson, F. R. Enzyme changes in the goldfish (Carassius auratus, L.) in responseto temperature acclimation. I. An immunohistochemical approach. II. Isozymes (PhD Thesis). Urbana, IL: Univ. of Illinois, 1973

46. Wodtke, E. Temperature adaptation of biological membranes. Compensation of the molar activity of cytochrome coxidase in the mitochondrial energy-transducing membrane during thermal acclimation of the carp (Cyprinus carpio L.). Biochim. Biophys. Acta 640: 710-720, 1981 